\title{
Effects of Fungicides, Time of Application, and Application Method on Control of Sclerotinia Blight in Peanut
}

\author{
Jason E. Woodward, ${ }^{1,2}$ Scott A. Russell, ${ }^{3}$ Michael R. Baring, \\ John M. Cason, ${ }^{5}$ and Todd A. Baughman ${ }^{6}$ \\ ${ }^{1}$ Texas A\&M AgriLife Extension Service, Lubbock, TX 79403, USA \\ ${ }^{2}$ Texas Tech University, Lubbock, TX 79409, USA \\ ${ }^{3}$ Texas A\&M AgriLife Extension Service, Brownfield, TX 79316, USA \\ ${ }^{4}$ Texas A\&M AgriLife Research, College Station, TX 77834, USA \\ ${ }^{5}$ Texas A\&M AgriLife Research, Stephenville, TX 76401, USA \\ ${ }^{6}$ Institute of Agricultural Biosciences, Oklahoma State University, Ardmore, OK 73401, USA
}

Correspondence should be addressed to Jason E. Woodward; jewoodward@ag.tamu.edu

Received 17 May 2015; Revised 16 September 2015; Accepted 20 September 2015

Academic Editor: Iskender Tiryaki

Copyright (C) 2015 Jason E. Woodward et al. This is an open access article distributed under the Creative Commons Attribution License, which permits unrestricted use, distribution, and reproduction in any medium, provided the original work is properly cited.

\begin{abstract}
Field studies were conducted from 2007 to 2010 to evaluate the response of peanut cultivars to different fungicides, application timings, and methods. Overall, fungicides reduced Sclerotinia blight incidence and increased pod yields when applied to susceptible and partially resistant cultivars. Disease suppression was greater when full fungicide rates were applied preventatively; however, yields between fungicide treated plots were similar. Lower levels of disease and higher yields were achieved with the partially resistant cultivar Tamrun OL07 compared to the susceptible cultivars Flavor Runner 458 and Tamrun OL 02. Despite possessing improved resistance Tamrun OL07 responded to all fungicide applications. While similar levels of disease control were achieved with broadcast or banded applications made during the day or at night, the yield response for the different application methods was inconsistent among years. A negative relationship (slope $=-73.8 ; R_{2}=0.73 ; P<0.01$ ) was observed between final disease incidence ratings and yield data from studies where a fungicide response was observed. These studies suggest that both boscalid and fluazinam are effective at controlling Sclerotinia blight in peanuts. Alternative management strategies such as nighttime and banded applications could allow for lower fungicide rates to be used; however, additional studies are warranted.
\end{abstract}

\section{Introduction}

Sclerotinia blight, caused by the soilborne fungus Sclerotinia minor (Jagger) [1], is a damaging disease of peanut (Arachis hypogaea L.). The disease was first reported in Virginia and North Carolina in 1971 and 1972, respectively [2]. In addition, S. sclerotiorum (Lib.) de Bary has recently been shown to incite the disease in the United States [3-5]. Crop losses exceeding 13\% were observed in Virginia in 1979 [6]. In Texas, yields losses of susceptible cultivars averaging $41 \%$ have been observed in fields severely infested with S. minor [7].

Initially, fungicides labeled for use in peanut provided only partial control of the disease [8]. The registration of iprodione for use in peanut in 1985 provided control between
45 and 55\% [9]. Porter [10] found that procymidone was highly effective at suppressing Sclerotinia blight in field studies and reducing fungal growth in vitro. Likewise, myclozolin was also effective in suppressing the disease when applied alone or in combination with other fungicides [11]. Research on these two compounds was discontinued due to regulatory issues regarding residues and toxicology. The fungicides dicloran and vinclozolin were granted emergencyuse labels in Virginia; however, full labels were never granted. Furthermore, studies have shown the potential of resistance and cross-resistance developing to these and other fungicides with similar modes of action $[9,12]$.

Fluazinam, a multisite inhibitor that possesses a high level of activity towards Sclerotinia blight, was registered for use in 
peanut in 2001 [13]. Smith [14] demonstrated that fluazinam is much more active against $S$. minor than iprodione and was equally effective on iprodione-resistant isolates of the fungus. Numerous studies have shown fluazinam to provide control of the disease when appropriate application rates are utilized [14-16]. Boscalid, a member of the second-generation succinate dehydrogenase inhibitors (SDHIs), was registered in 2003 and has been evaluated in spray regimes for the management of Sclerotinia blight $[17,18]$. Optimum disease control is achieved when applications are applied preventively or at the first sign of disease [16-18]. As a result several epidemiological models and algorithms have been developed to assist producers in characterizing the risk of $S$. minor infections and properly time fungicide applications [19-21].

Researchers screening genotypes have identified Spanish, runner, and Virginia cultivars and breeding lines with various levels of resistance to Sclerotinia blight [22-25]. As a result, partially resistant cultivars are generally used in conjunction with other tactics to manage the disease [26]. Despite possessing improved disease resistance, many cultivars positively respond to fungicide applications [7, 26-28]; however, yield increases seldom cover additional input costs. Various factors including application timing, method, and rate can affect fungicide efficacy. The majority of fungicides applications made to peanut are applied topically via a boom sprayer. This results in a large portion of the spray solution getting intercepted by the upper canopy, which reduces the amount of fungicide that actually reaches the target area where the plant is in direct contact with the soil surface. Infections of peanut by $S$. minor generally occur at the soil surface resulting from myceliogenic germination of sclerotia [29]; thus lower fungicide concentrations reaching the target can negatively affect efficacy. Various methods including banded applications vine pruning and use of a canopy opener have been used to try and improve fungicide penetration into the lower canopy $[16,27]$. Woodward et al. [30] evaluated the potential to redistribute fungicides to enhance control of southern stem rot, caused by Sclerotium rolfsii, by administering irrigation after fungicides were applied. Augusto et al. [31] enhanced control of southern stem rot by increasing spray deposition into the lower canopy by applying fungicides at night, when leaf configuration or folding occurs as a response to light-to-dark transitions [32]. Information on these techniques for managing Sclerotinia blight in the Southwestern United States is limited. Therefore, the first objective of this research was to compare preventative and curative fungicide applications. The second objective was to determine the effects of combinations of fungicide selection, application method, and timing on susceptible and partially resistant cultivars.

\section{Materials and Methods}

2.1. Fungicide Timing and Efficacy Trials. Field trials were conducted in 2007 and 2008 to evaluate the efficacy of preventative and curative applications of fungicides labeled for use in peanut. Trials were established at a producer farm in Western Gaines County, Texas $\left(32^{\circ} 50^{\prime} 8.55^{\prime \prime} \mathrm{N}, 103^{\circ} 2^{\prime} 22.80^{\prime \prime} \mathrm{W}\right)$, with a history of Sclerotinia blight. Soil type was a Brownfield or Patricia fine sand. Plots consisted of two $101.6 \mathrm{~cm}$ rows,
$15.2 \mathrm{~m}$ long, with $1.5 \mathrm{~m}$ alleys between plots. Peanuts (cv. Flavor Runner 458) [36] were planted on 1 May 2007 and 5 May 2008 at a rate of 5 seeds per $30.5 \mathrm{~cm}$. The experiment consisted of a two-by-three factorial plus a nontreated control, resulting in seven treatments arranged in a randomized complete block design with four replications. Treatments included applications of the fungicides boscalid (Endura, BASF Corporation, Research Triangle Park, NC) at $0.48 \mathrm{~kg}$ a.i. $\mathrm{ha}^{-1}$ and fluazinam (Omega, Syngenta Crop Protection, Greensboro, NC) at 0.58 and/or $0.88 \mathrm{~kg}$ a.i. $\mathrm{ha}^{-1}$ made on either a calendar basis (preventatively) or after disease onset (curatively). An additional treatment, comprised of four applications of chlorothalonil (Bravo WeatherStik, Syngenta Crop Protection) applied at a rate of $1.26 \mathrm{~kg}$ a.i. $\mathrm{ha}^{-1}$ $(60,75,90$, and 105 DAP), was included in 2007 for control of foliar diseases. Initial preventative applications of each fungicide and rate were made approximately 70 and 75 days after planting (DAP) in 2008 and 2007, respectively. In contrast, curative applications were made after the first sign of disease, approximately 86 DAP. Broadcast applications of fungicides were made using a $\mathrm{CO}_{2}$-pressurized backpack sprayer calibrated to deliver $187 \mathrm{~L} \mathrm{ha}^{-1}$ with two 8003 flat fan nozzles (TeeJet Technologies, Springfield, IL) per row. Local production practices, other than disease control, followed Texas A\&M AgriLife Extension recommendations [37].

2.2. Time of Application and Application Method Trials. Additional trials were conducted at the Gaines County location in 2008 with plot dimensions similar to those outlined in the previous section. In this study, a total of 11 treatments were evaluated and included broadcast and banded applications of full rates of boscalid and fluazinam (treatments 1-8) applied during the day (9:00 a.m. to 11:00 a.m.) or during the night (11:00 p.m. to 1:00 a.m.). Nighttime applications of reduced rates of fluazinam $\left(0.56 \mathrm{~kg}\right.$ a.i. ha $\left.{ }^{-1}\right)$ were also included (treatments 9 and 10) as was a nontreated control (treatment 11). Treatments were arranged in a randomized complete block with four replications. Initial applications were made 60 to $65 \mathrm{DAP}$ with sequential applications made 28 to 30 days later. The same treatments were evaluated in studies conducted at the Texas A\&M AgriLife Research and Extension Center in Stephenville, TX $\left(32^{\circ} 15^{\prime} 12.74^{\prime \prime} \mathrm{N}\right.$, $\left.98^{\circ} 11^{\prime} 29.63^{\prime \prime} \mathrm{W}\right)$, in 2009 and 2010. Soil type at this location was a Windthorst fine sandy loam. Plots consisted of two $91.4 \mathrm{~cm}$ rows, $7.6 \mathrm{~m}$ long, with $1.5 \mathrm{~m}$ alleys. The experimental design was a split-plot where fungicide treatments (described above) served as whole plots and the cultivars Flavor Runner 458 [36], Tamrun OL 02 [38], or Tamrun OL07 [39] served as subplots. There were a total of four replications per treatment cultivar combination. Planting was delayed until mid-June in order to prolong exposure to conditions conducive for Sclerotinia blight later in the season. All other production practices followed local recommendations [37]. Fungicides were applied 60 and 90 DAP during the same times specified in the studies outlined previously.

2.3. Assessing Sclerotinia Blight, Pod Yields, and Quality. Weather data were collected from regional weather stations 
TABLE 1: Monthly rainfall totals for the 2007, 2008, 2009, and 2010 growing seasons and the 30 -year average for Gaines County, Texas ${ }^{\mathrm{a}}$.

\begin{tabular}{lccccc}
\hline \multirow{2}{*}{ Month } & \multicolumn{5}{c}{ Rainfall $(\mathrm{mm})$} \\
& 2007 & 2008 & 2009 & 2010 & 30-year avg. \\
\hline April & 29 & 16 & 35 & 37 & 30 \\
May & 217 & 49 & 46 & 1 & 57 \\
June & 42 & 40 & 71 & 65 & 73 \\
July & 23 & 11 & 68 & 149 & 51 \\
August & 24 & 39 & 16 & 9 & 65 \\
September & 67 & 120 & 13 & 9 & 68 \\
October & 0 & 47 & 15 & 7 & 45 \\
\hline Total & 402 & 322 & 264 & 277 & 389 \\
\hline
\end{tabular}

${ }^{\mathrm{a}}$ Data were obtained from the West Texas Mesonet [33].

[33]. Sclerotinia blight was assessed prior to digging by counting the total number of disease foci per plot. Foci consisted of $30.5 \mathrm{~cm}$ segments of row exhibiting symptoms of the disease or signs of the pathogen [35]. Disease incidence was calculated using the following formula: $\%=[$ (number of affected $30.5 \mathrm{~cm}$ segments)/(total number of $30.5 \mathrm{~cm}$ segments in the plot)] $\times 100$. Pod maturity was assessed by destructively sampling adjacent border plots from each field [40]. Plots were mechanically dug and inverted using a KMC digger/shaker (Kelly Manufacturing Co., Tifton, GA) and allowed to dry in windrows for 5 to 7 days. Windrows were harvested using a two-row combine equipped with a sacking attachment (Lilliston Corporation, Albany, GA). Pod yields were calculated after foreign material and soil were removed and moisture was adjusted to $10 \%$ (wt/wt). Subsamples of pods $(500 \mathrm{~g})$ were then collected, shelled, sorted, and subjected to federal inspection procedures [41]. The sum of total sound mature kernels (TSMK) and sound splits (SS) was used to determine peanut grades (\% TSMK + SS).

2.4. Data Analysis. Disease incidence, yield, and grade data from trials for each of the two studies were subjected to analysis of variance [42]. For the timing and efficacy study, the model evaluated the effects of trial, treatment, and their interactions. Similarly, the effects of trial, treatment, cultivar, and the interactions were evaluated in the application timing and method study. Means were separated using Fischer's Protected LSD at $P \leq 0.05$ [34]. The relationship between yield and mean disease incidence ratings was investigated by combining data from all trials where a fungicide response was observed using linear regression [43].

\section{Results and Discussion}

Rainfall amounts in west Texas varied throughout the duration of these studies (Table 1). Conditions at the Stephenville location compared to the long term averages were generally similar (data not shown). Early season (April, May, and June) rainfall was $180,66,95$, and $64 \%$ of the 30 -year average in 2007, 2008, 2009, and 2010, respectively, whereas, rainfall averages during flowering, pegging, and pod fill [44] ranged from 15 to $176 \%$. Supplemental irrigation was applied as necessary during episodic periods of drought. Results from the two years where preventative and curative fungicide programs were evaluated are presented separately, as treatments differed among years. Significant treatment by year interactions were observed for the application techniques study; therefore, those data are presented by year; however, the lack of year by cultivar interactions within a given year allowed the data for all parameters to be combined.

3.1. Efficacy of Preventative and Curative Fungicide Applications. High disease pressure was observed in both years with disease incidence averaged across all treatments totaling 22.1 and 23.4\% in 2007 and 2008, respectively (Table 2). Sclerotinia blight was the predominant disease during both seasons; however, symptoms of early leaf spot were observed late in the season. Ratings were conducted prior to harvest, but no defoliation was observed (data not shown). Preventative applications of chlorothalonil were applied as a treatment in 2007 to examine the influence of leaf spot; however, previous studies have shown that applications of chlorothalonil aggravated Sclerotinia blight [45, 46]. Such results were not observed in this study, as there were no differences in final disease incidence, yields, or grades between the chlorothalonil treated and nontreated plots for (Table 2).

Langston et al. [20] discussed the importance of preventative fungicide applications in the management of Sclerotinia blight in Virginia. Producers in the High Plains of Texas scout fields regularly for diseases as a decision guide for making fungicide applications (personal observations). The application of fungicides reduced the level of disease compared to the nontreated control in both 2007 and 2008 (Table 2). Fungicide performance was similar for boscalid and fluazinam regardless of application timing in 2008. In 2007 , the full rate of fluazinam applied prior to the onset of disease provided the greatest level of control, whereas disease incidence among fungicide treatments was highest when boscalid was applied curatively. Disease control for all other fungicide treatments was intermediate. Despite differences in disease control, yields for fungicide treated plots were not significantly different providing an average increase over the nontreated control of 959 and $1726 \mathrm{~kg} \mathrm{ha}^{-1}$ in 2007 and 2008, respectively. Rideout et al. [47] found that differences in the expression of symptoms caused by $S$. rolfsii can affect the ability to accurately determine the relationship between yield and disease development. One limitation to using disease incidence to assess fungicide efficacy is that the value of mildly affected plants is equivalent to severely affected plants; however, the ease to measure disease incidence has been routinely been used to estimate severity [48]. While best management practices for controlling Sclerotinia blight should utilize preventative applications, erratic environmental conditions may limit the severity of the disease. This in conjunction with active scouting of fields may afford producers the opportunity to delay fungicide applications, where only a single application is required.

3.2. Effect of Fungicide Application Techniques on Sclerotinia Blight. The application of fungicides in a narrow band has 
TABLE 2: Comparison of fluazinam and boscalid fungicide programs applied prior to observing symptoms of Sclerotinia blight in peanut and after disease onset ${ }^{\mathrm{a}}$.

\begin{tabular}{|c|c|c|c|c|c|c|c|c|}
\hline \multirow{2}{*}{ Fungicide } & \multirow{2}{*}{$\begin{array}{c}\text { Rate } \\
\left(\mathrm{kg} \text { a.i. ha }{ }^{-1}\right)\end{array}$} & \multirow{2}{*}{ Timing } & \multicolumn{2}{|c|}{ Disease incidence (\%) } & \multicolumn{2}{|c|}{ Yield $\left(\mathrm{kg} \mathrm{ha}^{-1}\right)$} & \multicolumn{2}{|c|}{ Grade (\% TSMK + SS) } \\
\hline & & & 2007 & 2008 & 2007 & 2008 & 2007 & 2008 \\
\hline Nontreated control & $\mathrm{n} / \mathrm{a}$ & $\mathrm{n} / \mathrm{a}$ & $44.4^{\mathrm{a}}$ & $46.0^{\mathrm{a}}$ & $4731^{b}$ & $3015^{\mathrm{b}}$ & $77.2^{\mathrm{a}}$ & $75.4^{\mathrm{a}}$ \\
\hline Chlorothalonil & 1.12 & Preventative & $42.4^{\mathrm{a}}$ & - & $4361^{\mathrm{b}}$ & - & $76.9^{\mathrm{a}}$ & - \\
\hline Fluazinam & 0.58 & Preventative & - & $17.4^{\mathrm{b}}$ & - & $5032^{\mathrm{a}}$ & - & $74.8^{\mathrm{a}}$ \\
\hline Fluazinam & 0.88 & Preventative & $3.8^{\mathrm{e}}$ & $17.6^{\mathrm{b}}$ & $5589^{\mathrm{a}}$ & $4742^{\mathrm{a}}$ & $77.0^{\mathrm{a}}$ & $73.7^{\mathrm{a}}$ \\
\hline Boscalid & 0.48 & Preventative & $13.8^{\mathrm{cd}}$ & $20.8^{\mathrm{b}}$ & $6017^{\mathrm{a}}$ & $4829^{\mathrm{a}}$ & $76.6^{\mathrm{a}}$ & $74.4^{\mathrm{a}}$ \\
\hline Fluazinam & 0.58 & Curative & $14.6^{\mathrm{cd}}$ & - & $5351^{\mathrm{a}}$ & - & $77.1^{\mathrm{a}}$ & - \\
\hline Fluazinam & 0.88 & Curative & $15.2^{\mathrm{bcd}}$ & $16.4^{\mathrm{b}}$ & $5425^{\mathrm{a}}$ & $4768^{\mathrm{a}}$ & $76.8^{\mathrm{a}}$ & $73.7^{\mathrm{a}}$ \\
\hline Boscalid & 0.48 & Curative & $20.6^{\mathrm{bc}}$ & $22.0^{\mathrm{b}}$ & $6069^{\mathrm{a}}$ & $4336^{\mathrm{a}}$ & $77.5^{\mathrm{a}}$ & $73.2^{\mathrm{a}}$ \\
\hline
\end{tabular}

${ }^{\mathrm{a}} \mathrm{Data}$ are the mean of four replications. Values with common letter(s) within a column are not significantly different according to Fisher's Protected LSD $(P \leq$ 0.05) [34]. — indicates that treatments were evaluated.

TABLE 3: Effect of broadcast and banded applications of the fungicides boscalid and fluazinam applied at different times of the day on Sclerotinia blight of peanut ${ }^{\mathrm{a}}$.

\begin{tabular}{|c|c|c|c|c|c|}
\hline \multirow{2}{*}{$\begin{array}{l}\text { Timing, } \\
\quad \text { fungicide }\left(\mathrm{kg} \text { a.i. } \mathrm{ha}^{-1}\right)\end{array}$} & \multirow{2}{*}{$\begin{array}{l}\text { Application } \\
\text { method }\end{array}$} & \multicolumn{4}{|c|}{ Sclerotinia blight incidence (\%) } \\
\hline & & $2008 \mathrm{I}$ & $2008 \mathrm{II}$ & 2009 & 2010 \\
\hline \multicolumn{6}{|l|}{ Day } \\
\hline Boscalid (0.48) & Broadcast & $1.7^{\mathrm{a}}$ & $6.0^{\mathrm{bc}}$ & $23.5^{\mathrm{ef}}$ & $6.3^{\mathrm{bc}}$ \\
\hline Boscalid (0.48) & Banded & $0.3^{\mathrm{a}}$ & $3.3^{\mathrm{c}}$ & $30.8^{\text {def }}$ & $4.7^{\mathrm{c}}$ \\
\hline Fluazinam (0.88) & Broadcast & $0.7^{\mathrm{a}}$ & $6.3^{\mathrm{bc}}$ & $35.8^{\mathrm{cd}}$ & $7.2^{\mathrm{bc}}$ \\
\hline Fluazinam $(0.88)$ & Banded & $0.3^{\mathrm{a}}$ & $5.3^{\mathrm{bc}}$ & $44.0^{\mathrm{bc}}$ & $7.2^{\mathrm{bc}}$ \\
\hline \multicolumn{6}{|l|}{ Night } \\
\hline Boscalid (0.48) & Broadcast & $0.7^{\mathrm{a}}$ & $8.0^{\mathrm{bc}}$ & $19.8^{\mathrm{f}}$ & $13.3^{\mathrm{b}}$ \\
\hline Boscalid (0.48) & Banded & $2.7^{\mathrm{a}}$ & $5.7^{\mathrm{bc}}$ & $21.8^{\text {ef }}$ & $12.1^{\mathrm{b}}$ \\
\hline Fluazinam $(0.88)$ & Broadcast & $1.3^{\mathrm{a}}$ & $12.3^{\mathrm{b}}$ & $32.5^{\mathrm{de}}$ & $6.3^{\mathrm{bc}}$ \\
\hline Fluazinam (0.88) & Banded & $0.7^{\mathrm{a}}$ & $8.0^{\mathrm{bc}}$ & $41.5^{\mathrm{bcd}}$ & $7.5^{\mathrm{bc}}$ \\
\hline Fluazinam (0.58) & Broadcast & $0.7^{\mathrm{a}}$ & $9.0^{\mathrm{bc}}$ & $44.5^{\mathrm{bc}}$ & $9.2^{\mathrm{bc}}$ \\
\hline Fluazinam $(0.58)$ & Banded & $0.0^{\mathrm{a}}$ & $5.0^{\mathrm{bc}}$ & $48.3^{\mathrm{b}}$ & $9.0^{\mathrm{bc}}$ \\
\hline Nontreated control & $\mathrm{n} / \mathrm{a}$ & $1.7^{\mathrm{a}}$ & $21.3^{\mathrm{a}}$ & $61.8^{\mathrm{a}}$ & $23.8^{\mathrm{a}}$ \\
\hline \multicolumn{6}{|l|}{ Cultivar } \\
\hline Flavor Runner 458 & & 1.0 & 8.2 & $43.5^{\mathrm{A}}$ & $11.2^{\mathrm{A}}$ \\
\hline Tamrun OL 02 & & - & - & $42.8^{\mathrm{A}}$ & - \\
\hline Tamrun OL07 & & - & - & $23.8^{\mathrm{B}}$ & $8.1^{\mathrm{B}}$ \\
\hline
\end{tabular}

${ }^{a}$ Daytime applications were made between 9:00 a.m. and 11:00 a.m., whereas nighttime applications were made between 11:00 p.m. and 1:00 a.m. Disease incidence was assessed prior to the digging and inversion of plots [35]. Two trials (I and II) were conducted in Gaines County in 2008, whereas the trials from 2009 and 2010 were conducted at the Texas A\&M AgriLife Research and Extension Center in Stephenville. The number of replications for fungicide treatments varied by location totaling 4, 12, and 8 for trials in 2008, 2009, and 2010, respectively. Values within a column for each main effect are not different according to Fisher's Protected LSD $(P \leq 0.05)[34]$.

been evaluated for management of Sclerotinia blight. Damicone and Jackson [16] found that applying fluazinam in a $46 \mathrm{~cm}$ band using a single nozzle centered over the row provided greater control when using reduced rates. In this study, differences in application methods were observed in all trials except the 2008 I trial, where disease incidence was $<5 \%$ (Table 3 ). Disease incidence for Tamrun OL07 was 35 and $44 \%$ lower than the susceptible cultivars Flavor Runner 458 and Tamrun OL 02, respectively, which supports previous findings indicating that Tamrun OL07 has partial resistance to Sclerotinia blight $[7,23,39]$. Banded applications of fluazinam and boscalid did not improve the level of disease control provided by broadcast applications. Disease incidence was the highest in 2009 (ranging from 20 to 62\%). Symptom expression was more severe among treated plots than between years, which could be attributed to cool and humid conditions that may have reduced the residual activity of the fungicides (data not shown).

High yields were achieved in three of the four trials averaging 4060 and $5393 \mathrm{~kg} \mathrm{ha}^{-1}$ for the two Gaines County trials in 2008 and $5432 \mathrm{~kg} \mathrm{ha}^{-1}$ for the 2010 Stephenville trial (Table 4). Differences among treatments were observed in all trials except one of the 2008 Gaines County trials. Overall, broadcast and banded applications of fluazinam improved 
TABLE 4: Effect of broadcast and banded applications of the fungicides boscalid and fluazinam applied at different times of the day on peanut yield ${ }^{\mathrm{a}}$.

\begin{tabular}{|c|c|c|c|c|c|}
\hline \multirow{2}{*}{$\begin{array}{l}\text { Timing, } \\
\left.\quad \text { fungicide (kg a.i. } \mathrm{ha}^{-1}\right)\end{array}$} & \multirow{2}{*}{$\begin{array}{l}\text { Application } \\
\text { method }\end{array}$} & \multicolumn{4}{|c|}{ Pod yield $\left(\mathrm{kg} \mathrm{ha}^{-1}\right)$} \\
\hline & & $2008 \mathrm{I}$ & 2008 II & 2009 & 2010 \\
\hline \multicolumn{6}{|l|}{ Day } \\
\hline Boscalid (0.48) & Broadcast & $4551^{\mathrm{a}}$ & $5546^{\mathrm{ab}}$ & $3666^{\mathrm{a}}$ & $5303^{\mathrm{ab}}$ \\
\hline Boscalid (0.48) & Banded & $4480^{\mathrm{a}}$ & $5346^{\mathrm{b}}$ & $2779^{\mathrm{bcd}}$ & $6319^{a}$ \\
\hline Fluazinam (0.88) & Broadcast & $4107^{\mathrm{a}}$ & $6265^{\mathrm{a}}$ & $2806^{\mathrm{bc}}$ & $5471^{\mathrm{ab}}$ \\
\hline Fluazinam (0.88) & Banded & $4421^{\mathrm{a}}$ & $5589^{\mathrm{ab}}$ & $2221^{\text {cde }}$ & $5762^{\mathrm{ab}}$ \\
\hline \multicolumn{6}{|l|}{ Night } \\
\hline Boscalid (0.48) & Broadcast & $3371^{\mathrm{a}}$ & $5103^{b}$ & $3142^{\mathrm{ab}}$ & $5285^{\mathrm{b}}$ \\
\hline Boscalid (0.48) & Banded & $3928^{\mathrm{a}}$ & $5184^{\mathrm{b}}$ & $3088^{\mathrm{ab}}$ & $5860^{\mathrm{ab}}$ \\
\hline Fluazinam (0.88) & Broadcast & $4350^{\mathrm{a}}$ & $4994^{\mathrm{b}}$ & $2953^{\mathrm{b}}$ & $5280^{\mathrm{b}}$ \\
\hline Fluazinam (0.88) & Banded & $3549^{\mathrm{a}}$ & $6033^{a}$ & $2570^{\mathrm{bcd}}$ & $5663^{\mathrm{ab}}$ \\
\hline Fluazinam (0.58) & Broadcast & $3987^{\mathrm{a}}$ & $5627^{\mathrm{ab}}$ & $2228^{\text {cde }}$ & $5221^{b}$ \\
\hline Fluazinam (0.58) & Banded & $3874^{\mathrm{a}}$ & $5389^{\mathrm{b}}$ & $2194^{\mathrm{de}}$ & $5974^{\mathrm{ab}}$ \\
\hline Nontreated control & $\mathrm{n} / \mathrm{a}$ & $4042^{\mathrm{a}}$ & $4247^{\mathrm{c}}$ & $1697^{\mathrm{e}}$ & $3613^{\mathrm{c}}$ \\
\hline \multicolumn{6}{|l|}{ Cultivar means } \\
\hline Flavor Runner 458 & & 4060 & 5393 & $2439^{\mathrm{B}}$ & $4623^{\mathrm{B}}$ \\
\hline Tamrun OL 02 & & - & - & $2452^{\mathrm{B}}$ & - \\
\hline Tamrun OL07 & & - & - & $3259^{\mathrm{A}}$ & $5995^{\mathrm{A}}$ \\
\hline
\end{tabular}

${ }^{a}$ Daytime applications were made between 9:00 a.m. and 11:00 a.m., whereas nighttime applications were made between 11:00 p.m. and 1:00 a.m. Two trials (I and II) were conducted in Gaines County in 2008, whereas the trials from 2009 and 2010 were conducted at the Texas A\&M AgriLife Research and Extension Center in Stephenville. The number of replications for fungicide treatments varied by location totaling 4, 12, and 8 for trials in 2008 , 2009, and 2010, respectively. Values within a column for each main effect are not different according to Fisher's Protected LSD $(P \leq 0.05)[34]$.

yields from 1068 to $2001 \mathrm{~kg} \mathrm{ha}^{-1}$ compared to the nontreated control. Similar yields that were achieved for corresponding rates of boscalid or fluazinam were applied by either method.

In addition to using banded applications, Damicone and Jackson [16] used a canopy opener to improve penetration into the lower portions of the plant. Doing so reduced disease incidence compared to plots not receiving fluazinam. Few producers are equipped with implements that can be used to manipulate the plant canopy. Furthermore, physical damage peanut vines may predispose plants to infections by S. minor [49]. Applying fungicides at night takes advantage of natural changes in plant architecture that allows for better deposition in the lower canopy, including the crown [31]. When comparing day and night application timings, yields for both boscalid and fluazinam were similar (Table 4). Yields for plots receiving $0.58 \mathrm{~kg} \mathrm{ha}^{-1}$ fluazinam applied at night were equal to full rates applied at either timing. The incorporation of nighttime applications could allow producers to use lower rates of fungicides without compromising yield, thus maximizing profitability.

Damage caused by soilborne pathogens can lead to an increase in damaged kernels, resulting in a substantial reduction in value of the crop [41]. The percentage of TSMK + SS varied by trial; however, differences among fungicide treatments were not observed (Table 5). Grades were generally lower in trials conducted in Stephenville in 2009 and 2010. This is most likely due to the fact that planting was delayed so that exposure to conditions conducive to disease development would be prolonged. Previous studies have shown that, despite having improved Sclerotinia blight resistance, grades for Tamrun OL07 are significantly lower than grades of other commercial cultivars $[7,23,39]$. Similar trends were observed in this study, where grades for Tamrun OL07 were 1.9 to $3.5 \%$ lower than Flavor Runner 458 and 1.4\% lower than Tamrun OL 02 (Table 5).

\subsection{Relationship between Sclerotinia Blight and Peanut Yield.} Significant fungicide responses (disease control and yield) were observed in five of the six trials reported herein (Tables $2-4)$. The lack of a significant treatment $\times$ cultivar interaction, where applicable, allowed for treatments to be averaged over susceptible (Flavor Runner 458 and Tamrun OL 02) and partially resistant (Tamrun OL07) cultivars. There was no relationship observed between disease incidence and grade (data not shown). In the current study, yields were negatively correlated where the influence of final disease incidence on pod yield was highly significant $(P<0.01$; Figure 1$)$. The data were fitted to a linear model where $73.8 \%$ of the variability in yield loss was explained by Sclerotinia blight incidence before harvest. The intercept of the regression, which is an indicator of potential yield in the absence of disease, totaled $6017 \mathrm{~kg} \mathrm{ha}^{-1}$. Combined data were found to be normally distributed ( $P=0.1896)$, according to Shapiro and Wilk [50].

Information pertaining to the relationship between Sclerotinia blight and yield is limited. Most models used to predict yield loss utilize area under disease progress curves (AUDPC) values as described by Shaner and Finney [51]. Damicone and Jackson [16] showed that both final disease incidence and AUDPC adequately characterized the yield loss relationship with fluazinam and to a lesser degree iprodione. 
TABLE 5: Effect of broadcast and banded applications of the fungicides boscalid and fluazinam applied at different times of the day on peanut grade $^{\mathrm{a}}$.

\begin{tabular}{|c|c|c|c|c|c|}
\hline \multirow{2}{*}{$\begin{array}{l}\text { Timing, } \\
\quad \text { fungicide }\left(\mathrm{kg} \text { a.i. } \mathrm{ha}^{-1}\right)\end{array}$} & \multirow{2}{*}{$\begin{array}{c}\text { Application } \\
\text { method }\end{array}$} & \multicolumn{4}{|c|}{ Grade (\% TSMK + SS) } \\
\hline & & $2008 \mathrm{I}$ & 2008 II & 2009 & 2010 \\
\hline \multicolumn{6}{|l|}{ Day } \\
\hline Boscalid (0.48) & Broadcast & $70.1^{\mathrm{a}}$ & $76.3^{\mathrm{a}}$ & $66.1^{\mathrm{a}}$ & $68.7^{\mathrm{a}}$ \\
\hline Boscalid (0.48) & Banded & $66.6^{\mathrm{a}}$ & $75.3^{\mathrm{a}}$ & $65.0^{\mathrm{a}}$ & $66.9^{\mathrm{a}}$ \\
\hline Fluazinam (0.88) & Broadcast & $69.3^{\mathrm{a}}$ & $75.9^{\mathrm{a}}$ & $66.5^{\mathrm{a}}$ & $67.7^{\mathrm{a}}$ \\
\hline Fluazinam (0.88) & Banded & $70.3^{\mathrm{a}}$ & $75.1^{\mathrm{a}}$ & $65.9^{\mathrm{a}}$ & $67.3^{\mathrm{a}}$ \\
\hline \multicolumn{6}{|l|}{ Night } \\
\hline Boscalid (0.48) & Broadcast & $68.8^{\mathrm{a}}$ & $75.5^{\mathrm{a}}$ & $66.1^{\mathrm{a}}$ & $68.2^{\mathrm{a}}$ \\
\hline Boscalid (0.48) & Banded & $68.3^{\mathrm{a}}$ & $75.4^{\mathrm{a}}$ & $66.3^{\mathrm{a}}$ & $66.9^{\mathrm{a}}$ \\
\hline Fluazinam (0.88) & Broadcast & $70.5^{\mathrm{a}}$ & $76.6^{\mathrm{a}}$ & $65.9^{\mathrm{a}}$ & $68.1^{\mathrm{a}}$ \\
\hline Fluazinam (0.88) & Banded & $70.5^{\mathrm{a}}$ & $73.7^{\mathrm{a}}$ & $65.3^{\mathrm{a}}$ & $67.9^{\mathrm{a}}$ \\
\hline Fluazinam (0.58) & Broadcast & $67.1^{\mathrm{a}}$ & $76.9^{\mathrm{a}}$ & $65.7^{\mathrm{a}}$ & $68.5^{\mathrm{a}}$ \\
\hline Fluazinam (0.58) & Banded & $69.1^{\mathrm{a}}$ & $75.7^{\mathrm{a}}$ & $66.0^{\mathrm{a}}$ & $67.4^{\mathrm{a}}$ \\
\hline Nontreated control & $\mathrm{n} / \mathrm{a}$ & $72.3^{\mathrm{a}}$ & $75.2^{\mathrm{a}}$ & $65.8^{\mathrm{a}}$ & $67.6^{\mathrm{a}}$ \\
\hline \multicolumn{6}{|l|}{ Cultivar } \\
\hline Flavor Runner 458 & & 69.4 & 75.6 & $67.2^{\mathrm{A}}$ & $68.2^{\mathrm{A}}$ \\
\hline Tamrun OL 02 & & - & - & $65.1^{\mathrm{AB}}$ & - \\
\hline Tamrun OL07 & & - & - & $63.7^{\mathrm{B}}$ & $66.3^{\mathrm{B}}$ \\
\hline
\end{tabular}

${ }^{a}$ Daytime applications were made between 9:00 a.m. and 11:00 a.m., whereas nighttime applications were made between 11:00 p.m. and 1:00 a.m. Two trials (I and II) were conducted in Gaines County in 2008, whereas the trials from 2009 and 2010 were conducted at the Texas A\&M AgriLife Research and Extension Center in Stephenville. The number of replications for fungicide treatments varied by location totaling 4,12 . and 8 for trials in 2008,2009 , and 2010 , respectively. Values within a column for each main effect are not different according to Fisher's Protected LSD $(P \leq 0.05)[34]$.

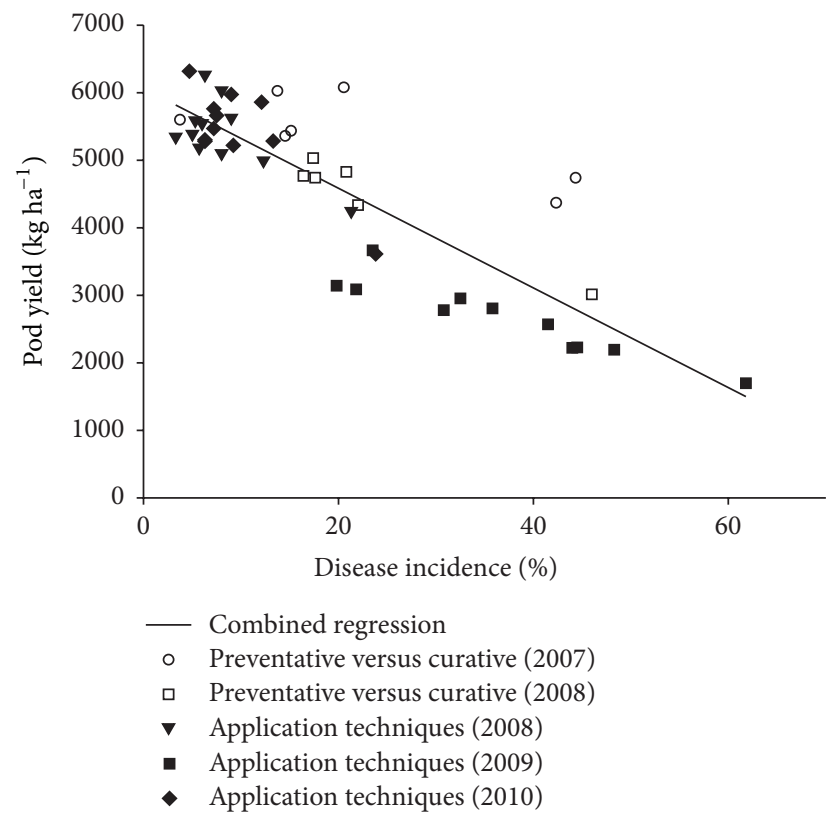

FIGURE 1: Effect of final Sclerotinia blight incidence on peanut yield from five fungicide trials conducted from 2007 to 2010. Data represent the mean of fungicide treatments across replications $(n=$ 4 ) and cultivars ( $n=8$ to 12 ), where fungicide responses were observed. The solid line represents the relationship between the percent disease incidence (DI) and pod yield $(Y)$. The regression equation, coefficient of determination, and $P$ value are $Y=6061-$ 73.8DI, $R_{2}=0.73$, and $P<0.01$, respectively.
In the current studies, similar relationships between final disease incidence and yield loss have been observed (Woodward, unpublished); thus only final disease ratings were included in the aforementioned analyses.

\section{Conclusions}

Sclerotinia blight is an economically important disease of peanut in the United States and is capable of being incited by $S$. minor and to a lesser degree S. sclerotiorum. Since the identification of S. minor in Virginia in 1971, the disease has been reported in North Carolina, Oklahoma, and Texas with minor occurrences in Georgia and New Mexico. In addition to causing significant yield loss, management of the disease requires the integration of several practices. While crop with nonhosts is commonly implemented, the advent of fungicides with activity against Sclerotinia spp. has greatly enhanced the ability of producers to limit losses. Unfortunately, these products are expensive and often comprise a large proportion of production budgets [37]. In addition to fungicides, the release of cultivars with increased resistance has greatly improved production in fields with a severe history of the disease. The application of fungicides decreased disease incidence and increased yield, on susceptible and resistant cultivars in these and other studies $[7,28]$.

While a number of forecast models have been developed for timing fungicide applications in Virginia and North Carolina, application timings in Texas are based on days after 
planting or intensive scouting. Results from the first set of experiments conducted indicated that preventative calendarbased applications provided the highest level of control; however, yields among treatments were similar. Application methods that concentrate fungicides closer to the infection courts should increase efficacy. In general, there were few differences between broadcast and banded applications of boscalid and fluazinam applied at full rates. Results from these studies suggest that making applications at night when leaves are folded could allow for the use of reduced rates; however, additional studies are warranted.

The damage potential of Sclerotinia blight is often referenced; however, there are few published reports of relationships between the disease measurements and yield loss. Rather estimates of losses are made from surveys or field assessments $[6,52]$. In this study, final disease incidence was used to assess yield loss relationships and proved to be a good indicator of yield loss. Incorporating disease severity ratings into the model could increase accuracy in determining yield loss; however, such ratings are more subjective and may be affected by other factors, such as environmental conditions or other diseases. Furthermore, the method used to assess disease in this study differs from that used by Smith et al. [53] where the number of newly infected plants was measured to calculate a weekly incremental disease incidence. Such a method provides detailed information allowing for the detail modeling of Sclerotinia epidemics, whereas the method employed here provided a quick and reliable means of measuring disease.

\section{Conflict of Interests}

The authors declare that there is no conflict of interests regarding the publication of this paper.

\section{Acknowledgments}

This work was funded in part through grants from the Texas Peanut Producer Board and the National Peanut Producer Board. The technical support of Ira Yates, Max Batla, and Mitchell Ratliff is greatly appreciated. Special appreciation is expressed to Syngenta Crop Protection and BASF Corporation for providing fungicides. The authors thank Katie Lewis and Peter Dotray for their comments and suggestions in the preparation of this paper.

\section{References}

[1] L. Kohn, "A monographic revision of the genus Sclerotinia," Mycotaxon, vol. 9, no. 2, pp. 365-444, 1979.

[2] D. M. Porter and M. K. Beute, "Sclerotinia blight of peanut," Phytopathology, vol. 64, no. 2, pp. 263-264, 1974.

[3] J. E. Woodward, T. B. Brenneman, R. C. Kemerait Jr., A. K. Culbreath, and J. R. Clark, "Sclerotinia blight in georgia and evidence for resistance to Sclerotinia sclerotiorum in runner peanuts," Plant Health Progress, 2006.

[4] S. Sanogo and N. Puppala, "Characterization of a darkly pigmented mycelial isolate of Sclerotinia sclerotiorum on valencia peanut in New Mexico," Plant Disease, vol. 91, no. 9, pp. 10771082, 2007.
[5] J. E. Woodward, C. Nui, R. J. Wright, M. A. Batla, and T. A. Baughman, "First report of Sclerotinia sclerotiorum infecting peanut in Texas," Plant Disease, vol. 92, no. 10, article 1468, 2008.

[6] S. D. Thomas, N. L. Powell, D. M. Porter, and P. M. Phipps, "Use of infrared photography to determine estimates of peanut crop losses due to Sclerotiniablight," Proc. Am. Peanut Res. Educ. Soc., vol. 13, p. 90, 1981.

[7] J. E. Woodward, T. A. Baughman, M. R. Baring, and C. E. Simpson, "Comparison of three high-oleic peanut cultivars under varying field conditions in the Southwestern United States," Peanut Science, vol. 42, no. 1, pp. 11-17, 2015.

[8] M. K. Beute, D. M. Porter, and B. A. Hadley, "Sclerotinia blight of peanut in North Carolina and Virginia and its chemical control," Plant Disease Reporter, vol. 59, pp. 697-701, 1975.

[9] T. B. Brenneman, P. M. Phipps, and R. J. Stipes, "Control of Sclerotinia blight of peanut: sensitivity and resistance of Sclerotinia minor to vinclozolin, iprodione, dicloran, and PCNB," Plant Disease, vol. 71, pp. 87-90, 1987.

[10] D. M. Porter, "Control of Sclerotinia blight of peanut with procymidone," Plant Disease, vol. 64, no. 9, pp. 865-867, 1980.

[11] D. E. Dougherty, D. J. Sarojak, and F. Locher, "Fungicides for reducing losses caused by Sclerotinia blight on peanut," Plant Disease, vol. 67, no. 3, pp. 312-314, 1983.

[12] D. M. Porter and P. M. Phipps, "Effects of three fungicides on mycelial growth, Sclerotium production, and development of fungicide-tolerant isolates of Sclerotinia minor," Plant Disease, vol. 69, no. 2, pp. 143-146, 1985.

[13] Omega fungicide now registered on potatoes and peanuts, Plant Management Network, 2001, http://www.plantmanagementnetwork.org/pub/php/news/omega823/.

[14] F. D. Smith, "Agar plate, soil plate, and field evaluation of fluazinam and other fungicides for control of Sclerotinia minor on peanut," Plant Disease, vol. 75, no. 11, pp. 1138-1143, 1991.

[15] F. D. Smith, P. M. Phipps, and R. J. Stipes, "Fluazinam: a new fungicide for control of Sclerotinia blight and other soilborne pathogens of peanut," Peanut Science, vol. 19, no. 2, pp. 115-120, 1992.

[16] J. P. Damicone and K. E. Jackson, "Effects of application method and rate on control of Sclerotinia blight of peanut with iprodione and fluazinam," Peanut Science, vol. 28, no. 1, pp. 28-33, 2001.

[17] J. P. Damicone, K. E. Jackson, and K. E. Dashiell, "Response of peanut cultivars to fluazinam and boscalid for control of Sclerotinia blight," Proceedings of the American Peanut Research and Education Society, vol. 36, pp. 49-50, 2004.

[18] D. L. Smith, M. C. Garrison, J. E. Hollowell, T. G. Isleib, and B. B. Shew, "Evaluation of application timing and efficacy of the fungicides fluazinam and boscalid for control of Sclerotinia blight of peanut," Crop Protection, vol. 27, no. 3-5, pp. 823-833, 2008.

[19] P. M. Phipps, "An assessment of environmental conditions preceding outbreaks of Sclerotinia blight of peanut in Virginia," Peanut Science, vol. 22, no. 2, pp. 90-93, 1995.

[20] D. B. Langston Jr., P. M. Phipps, and R. J. Stipes, “An algorithm for predicting outbreaks of Sclerotinia blight of peanut and improving the timing of fungicide sprays," Plant Disease, vol. 86, no. 2, pp. 118-126, 2002.

[21] D. L. Smith, J. E. Hollowell, T. G. Isleib, and B. B. Shew, "Analysis of factors that influence the epidemiology of Sclerotinia minor on peanut," Plant Disease, vol. 90, no. 11, pp. 1425-1432, 2006. 
[22] C. N. Akem, H. A. Melouk, and O. D. Smith, "Field evaluation of peanut genotypes for resistance to Sclerotinia blight," Crop Protection, vol. 11, no. 4, pp. 345-348, 1992.

[23] M. R. Baring, C. E. Simpson, M. D. Burow, J. M. Cason, and J. L. Ayers, "Registration of 'Tamrun OL11' peanut," Journal of Plant Registrations, vol. 7, no. 2, pp. 154-158, 2013.

[24] T. A. Coffelt and D. M. Porter, "Screening peanuts for resistance to Sclerotinia blight," Plant Disease, vol. 66, no. 1, pp. 385-387, 1982.

[25] J. E. Hollowell, B. B. Shew, and T. G. Isleib, "Evaluating isolate aggressiveness and host resistance from peanut leaflet inoculations with Sclerotinia minor," Plant Disease, vol. 87, no. 4, pp. 402-406, 2003.

[26] D. M. Porter and A. H. Melouk, "Sclerotinia bligh," in Compendium of Peanut Diseases, N. Kokalis-Burelle, D. M. Porter, R. Rodriquez-Kabana, D. H. Smith, and P. Subrahmanyam, Eds., pp. 34-36, American Phytopathological Society, St. Paul, Minn, USA, 2nd edition, 1997.

[27] T. M. Butzler, J. Bailey, and M. K. Beute, "Integrated management of Sclerotinia blight in peanut: utilizing canopy morphology, mechanical pruning, and fungicide timing," Plant Disease, vol. 82, no. 12, pp. 1312-1318, 1998.

[28] J. P. Damicone and K. E. Jackson, "Disease and yield responses to fungicides among peanut cultivars differing in reaction to Sclerotinia blight," Peanut Science, vol. 23, no. 2, pp. 81-85, 1996.

[29] R. L. Dow, D. M. Porter, and N. L. Powell, "Effects of environmental factors on Sclerotinia minor and Sclerotinia blight of peanut," Phytopathology, vol. 78, no. 6, pp. 672-676, 1988.

[30] J. E. Woodward, T. B. Brenneman, and B. G. Mullinix Jr., "Irrigation timing impacts the efficacy of foliar-applied fungicides toward foliar and soilborne pathogens of peanut," Plant Disease, vol. 96, no. 12, pp. 1785-1790, 2012.

[31] J. Augusto, T. B. Brenneman, A. K. Culbreath, and P. Sumner, "Night spraying peanut fungicides II. Application timings and spray deposition in the lower canopy," Plant Disease, vol. 94, no. 6, pp. 683-689, 2010.

[32] D. Koller, "Light-driven leaf movements," Plant, Cell and Environment, vol. 13, no. 7, pp. 615-632, 1990.

[33] West Texas Mesonet, "Summaries, 2007-2010," 2015, http:// www.mesonet.ttu.edu/.

[34] R. A. Fisher, Statistical Methods, Experimental Design, and Scientific Inference, Oxford University Press, 1990.

[35] R. Rodriguez-Kabana, P. A. Backman, and J. C. Williams, "Determination of yield losses to Sclerotium rolfsii in peanut fields," Plant Disease Report, vol. 59, pp. 855-858, 1975.

[36] J. Beasley and J. Baldwin, "Peanut cultivar options and descriptions," 2009, http://www.caes.uga.edu/commodities/fieldcrops/ peanuts/production/cultivardescription.html.

[37] T. Baughman, P. Dotray, W. Grichar et al., Texas Peanut Production Guide, Texas A\&M University, 2007.

[38] C. E. Simpson, M. R. Baring, A. M. Schubert, M. C. Black, H. A. Melouk, and Y. Lopez, "Registration of 'Tamrun OL 02' peanut," Crop Science, vol. 46, no. 4, pp. 1813-1814, 2006.

[39] M. R. Baring, C. E. Simpson, M. D. Burow et al., "Registration of 'Tamrun OL07' peanut," Crop Science, vol. 46, no. 6, pp. 27212722, 2006.

[40] E. J. Williams and J. S. Drexler, "A non-destructive method for determining peanut pod maturity," Peanut Science, vol. 8, no. 2, pp. 134-141, 1981.

[41] USDA, "2014 Guidelines for Peanut Marketing Activity," 2015, http://www.fsa.usda.gov/Internet/FSA_File/2014peanut_ marketing_activity.pdf.
[42] SAS Institute, SAS/STAT User's Guide: Statistics, version 9.3, SAS Institute, Cary, NC, USA, 2011.

[43] Systat Software, SigmaPlot 12.5 User's Guide, Systat Software, San Jose, Calif, USA, 2013.

[44] K. J. Boote, "Growth stages of peanut (Arachis hypogaea L.)," Peanut Science, vol. 9, pp. 35-40, 1982.

[45] D. M. Porter, "Increased severity of Sclerotinia blight in peanuts treated with captafol and chlorothalonil," Plant Disease, vol. 64, no. 4, pp. 394-395, 1980.

[46] F. C. Hau and M. K. Beute, "Effects of chlorothalonil on the virulence and physiology of a nontargeted pathogen, Sclerotinia minor," Phytopathology, vol. 73, no. 3, pp. 475-479, 1983.

[47] S. L. Rideout, T. B. Brenneman, and K. L. Stevenson, "A comparison of disease assessment methods for southern stem rot of peanut," Peanut Science, vol. 29, no. 1, pp. 66-71, 2002.

[48] R. C. Seem, "Disease incidence and severity relationships," Annual Review of Phytopathology, vol. 22, no. 1, pp. 133-150, 1984.

[49] D. M. Porter and N. L. Powell, "Sclerotinia blight development in peanut vines injured by tractor tires," Peanut Science, vol. 5, no. 2, pp. 87-90, 1978.

[50] S. S. Shapiro and M. B. Wilk, "An analysis of variance test for normality (complete samples)," Biometrika, vol. 52, no. 3-4, pp. 591-611, 1965.

[51] G. Shaner and R. E. Finney, "The effect of nitrogen fertilization on the expression of slow-mildewing resistance in Knox wheat," Phytopathology, vol. 67, pp. 1051-1056, 1977.

[52] D. M. Porter, N. L. Powell, and P. R. Cobb, "Severity of Sclerotinia blight of peanuts as detected by infrared aerial photography," Peanut Science, vol. 4, no. 2, pp. 75-77, 1977.

[53] D. L. Smith, J. E. Hollowell, T. G. Isleib, and B. B. Shew, "A sitespecific, weather-based disease regression model for Sclerotinia blight of peanut," Plant Disease, vol. 91, no. 11, pp. 1436-1444, 2007. 


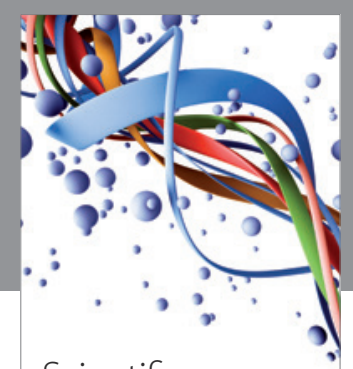

Scientifica
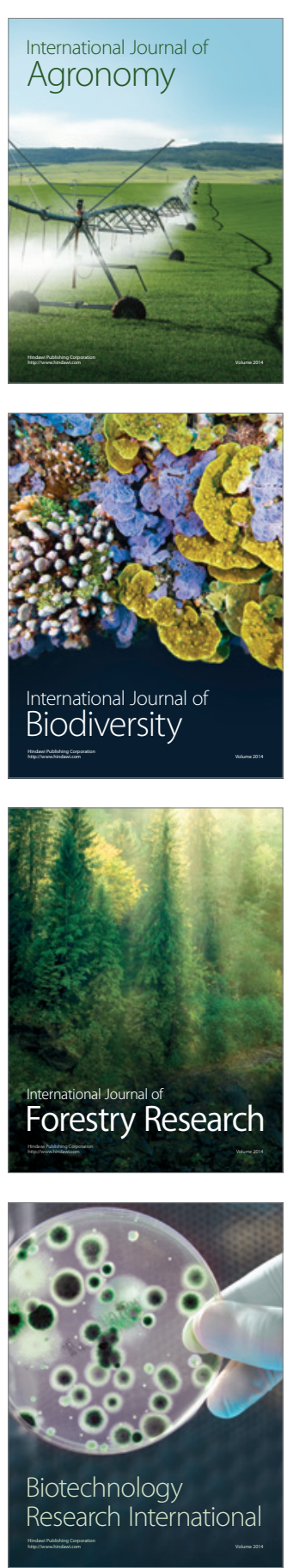
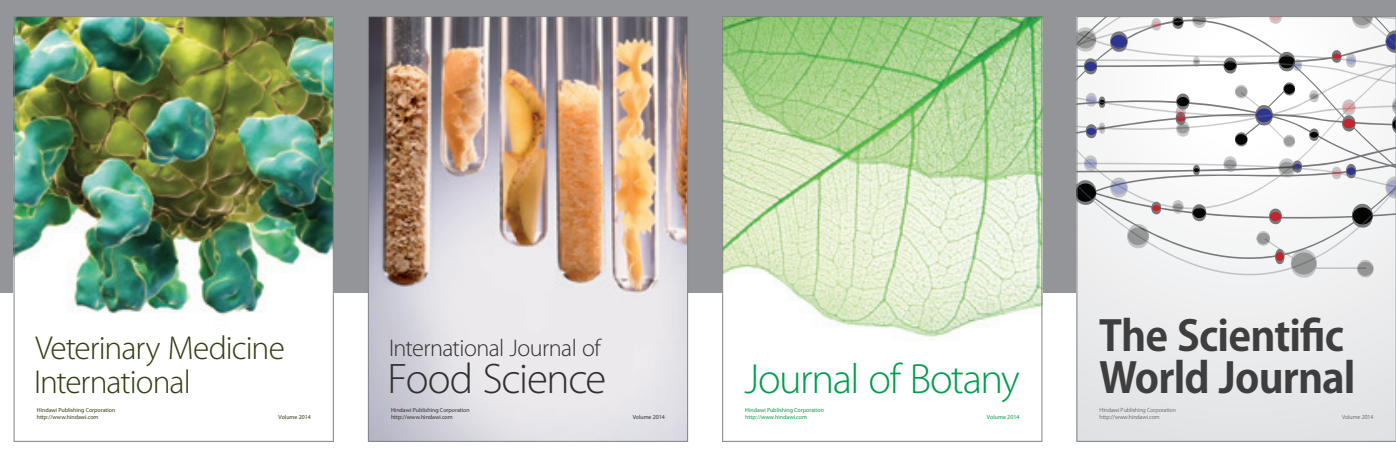

The Scientific World Journal
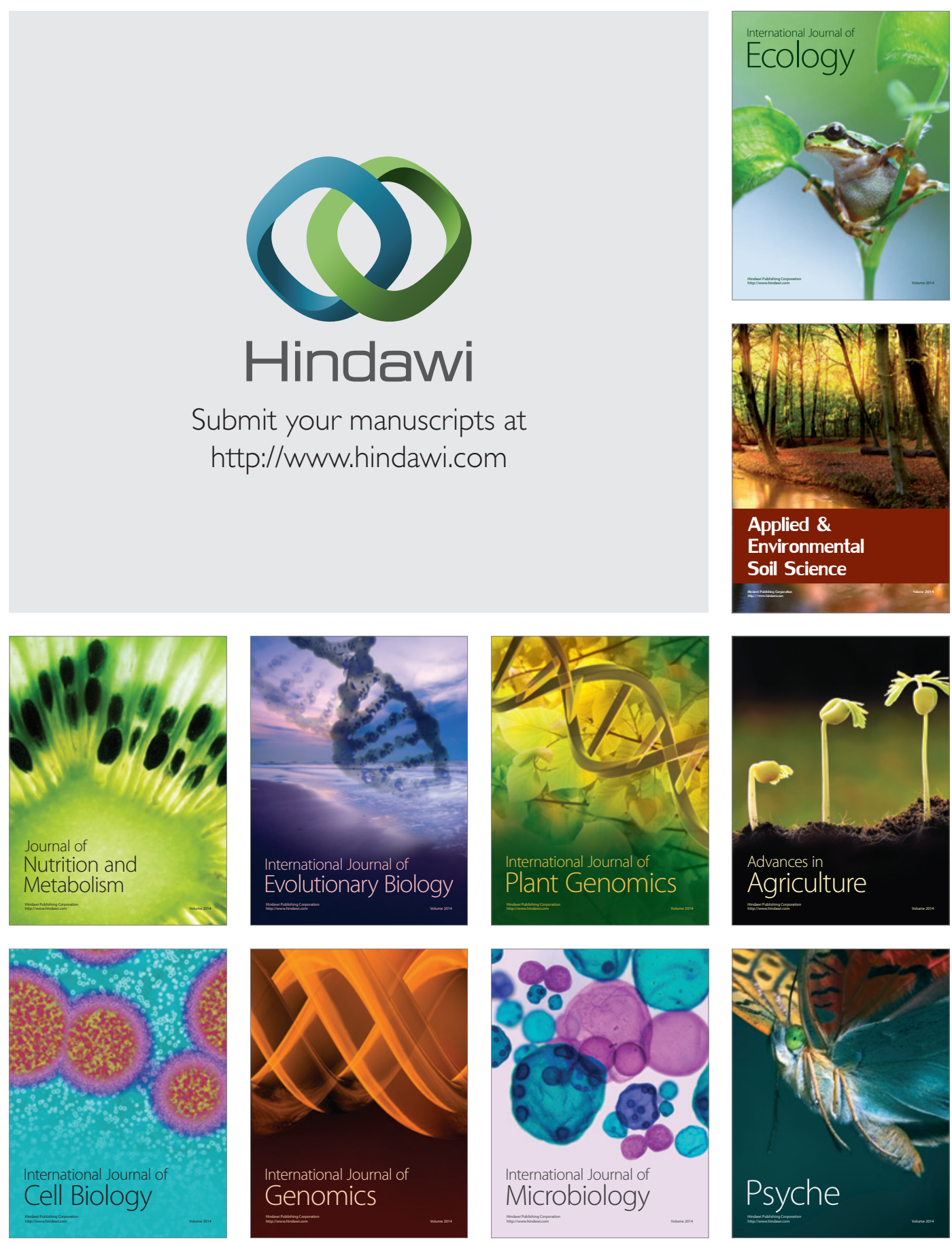